\title{
EVALUATION OF FACIAL AESTHETIC PROFILE IN UNIVERSITY STUDENTS: A PILOT STUDY
}

Cesario Rui Callou Filho; Brennda Kayane Flora Nogueira; Núbia de Fátima Costa Oliveira, Michelli Caroline de Camargo Barbosa. Ethel Esthephane Alves Vieira; Ádamo de Figueiredo Nogueira Mesquita; Aline Barbosa Teixeira Martins

\begin{abstract}
Introduction: Consequences on the face cause several symptoms of rejection, so the skin exam is essential for a specific treatment according to the aesthetic needs of each individual. Objective: To evaluate the facial aesthetic profile in university students. Methods: Cross-sectional study with university students, independent of gender and in the age group of 18 to 59 years old, from May to June 2019. A facial evaluation questionnaire was applied based on the main aesthetic complaints and the data were analyzed using SPSS version 20.0. Results: Most university students were female $(n=119)$, mean age 22 years old, and acne was the most frequent disease $(100 \%)$, especially moderate acne $(53.5 \%)$. Melasma was identified in $17.3 \%$, mainly in females $(74.2 \%)$. There were poor nutrition and irregular skin care without using sunscreen and other skin care routine. The side effects may include emergence of acne and melasma. Conclusion: Risk factors and irregular skin care may lead to facial skin lesions.
\end{abstract}

Keywords: Acne Vulgaris; Melanosis; Students; Face; Esthetics. 


\section{INTRODUCTION}

Aesthetics refers to the appreciation of beauty or the qualities that provide intense pleasure to our senses ${ }^{1}$. However, we are influenced by the media and when we escape from of the beauty standard we need to get products and treatments to correct the imperfections of the body that sometimes cause us dissatisfaction².

In aesthetics, the face can be affected by skin changes based on complex anatomical features ${ }^{3}$ that sometimes interfere with appearance - beauty.

Assessing imperfections and sequelae in the face, individual perception of aesthetics and attractiveness is influenced by combined factors, including anatomical characteristics ${ }^{4}$; psychosocial states ${ }^{5}$ such as self-esteem, cultural background and age; and three-dimensional movements as facial expressions ${ }^{6}$. The patient evaluation is a safe and essential procedure performed by the professional and it allows defining a specific and appropriate clinical protocol for the patient ${ }^{7}$.

Most frequent changes are acne ${ }^{8}$, melasma ${ }^{9}$, flaccidity of the face ${ }^{10}$, scars, oiliness, comedones, among other changes ${ }^{11}$. They cause dissatisfaction with the appearance and develop obsession with a self-image defect that they believe they possess and consequently cause problems in well-being, depression, reduced selfesteem and affect social and professional relationships ${ }^{12,13}$.

So, assuming that facial examination is fundamental to proper treatment, this study aimed to describe the assessment of the facial aesthetic profile in university students.

\section{METHODS}

This is a cross-sectional study, developed in a clinic-school in Ceará, during the months of May to June 2019, three times a week (on alternate days), in the morning and evening periods.

The group is composed by 18 years old university students from different genders, course and semester. For exclusion criteria was determined the elimination of those who had difficulties in understanding the form during the filling, pregnant women and individuals with diagnosis or apparent traumatic injury in the skin and/or face. 
The quantitative of the research was formed through calculation, presenting a sample error of $5 \%$, confidence level of $95 \%$, population of 1,670 academics with a minimum percentage of $50 \%$, wishing a quantitative of 313 university students.

For the collection instrument, a questionnaire was prepared by the researchers based on a study ${ }^{14}$ that addresses the socio-economic profile variables (gender, age, religion, course and semester, self-reported skin color, household income) and facial evaluation variables ${ }^{15}$ based on the Facial Evaluation Chart addressing contraceptive use (for women), smoking, alcoholism, skin types, acne sequelae, sunlight exposure acne satisfaction, performing some treatment, use of makeup, skin hygiene after using makeup and stress. The questions that guide the eating pattern and photoprotection were based on a survey ${ }^{16}$ concerning the evaluation of acne degree and the presence of melasma ${ }^{17}$.

For the collection, the researchers first publicized and invited the university students to participate in the study in the places they mostly attended at the University. The approach was randomized and contact was made through conversations that explained the objective of the study, presentation of the acceptance term and collection instrument.

If the university students agreed to participate in the research, they were guided by a researcher to the collection point and the term of acceptance and the research form were presented. After filling out the form, a facial examination was performed.

After data collection, the information were scanned to Microsoft Excel 2010 and analyzed using the Statistical Pockage for the Social Sciences (SPSS) for Windows version 23.0, standardizing statistical significance with values of $p<0.005$ with $95 \%$ confidence interval $(\mathrm{Cl})$, according to the study ${ }^{18}$.

For questions with numerical values, the Kolmogorov-Smirnov (KS) normality test was applied, with no non-normal distribution ( $\mathrm{sig}=0.000)$. For variables as "NOT normal", the group comparison test was performed, the "Kruskal Wallis" test. Subsequently, we applied the Mann-Whitney peer-to-peer test which resulted in the following: significant statistical difference between the white and brown skin type $(p=0.013)$ and between the brown and black skin type $(p=0.001)$.

Some statistical analyses occurred in the study and the results were presented in a descriptive way through the frequency and percentage of all the results. The researchers emphasize that the variables age and acne degree presented statistically 
significant value $p<000$ through the Mann-Whitney test. The Kruskal Wallis test was adopted in relation to the degree of acne and the age of the participants. The approach of acne degree and the presence of acneic scar occurred through the Chi-square test.

This research was approved by the Research Ethics Committee of Centro Universitário Dr. Leão Sampaio (CEP/UNILEÃO), under registration 3.261.706 and used the signature of the Participant Informed Consent Form.

\section{RESULTS}

At the end of the collection, we obtained ( $n=179)$ university students, mean age of 22 years old with Standard Deviation $(S D= \pm 4)$ and $50 \%$ of university students aged up to 21 years old.

The majority students $(66.5 \%)$ are female and $40.8 \%$ of this percentage declared using contraception. For religious practices, $(n=158 ; 88.2 \%)$ declared belonging to some religion, while $(n=21 ; 11.7 \%)$ has no religion. The majority are students of Physiotherapy ( $n=83 ; 46.4 \%)$, followed by Psychology $(n=29 ; 16.2 \%)$ and in lower number, the course of Social Work $(n=1 ; 0.6 \%)$.

The self-reported brown skin color $(n=110 ; 61.5 \%)$ was the most frequent, followed by the white color ( $n=47 ; 23.6 \%$ ). A comparison (Mann-Whitney " peer-to-peer " tes ${ }^{1}$ ) was performed between the degree of acne (Cl: 1.85-2.08) and skin type and a statistically significant difference was observed between white and brown skin type (Cl: 2.29-2.47; $p=0.013)$ and between brown and black skin type $(p=0.001)$. The household income $(n=151 ; 84.4 \%)$ was between one and three brazilian minimum wages.

In table I the data show the self-declared habits of university students, corresponding to eating habits, alcohol and other drugs. The highest percentages were for frying $(78.8 \%)$, fruits $(77.7 \%)$, alcohol $(55.9 \%)$ and other drugs $(97.8 \%)$.

\section{Table I}

Table II shows the variables for evaluating the face, measures to prevent facial skin lesions, and face care. The skin scar data shows that university students had $(\mathrm{n}=102 ; 57 \%)$ acneic scars, and women had $(\mathrm{n}=62 ; 60.8 \%)$ skin lesions.

Examining the face with acne, the authors observed that grade II, with the presence of papular-pustular lesions, showed a higher percentage (53.6\%), followed Revista Inova Saúde, Criciúma, vol. 11, n. 2, julho, 2021. ISSN 2317-2460 
by grade I ( $27.9 \%)$, with comedones for grade III $(12.3 \%)$ and only $6.1 \%$ had grade IV acne. The majority of the participants presented $48 \%$ for mixed skin, followed by $45.3 \%$ for oily skin and $6.7 \%$ for dry skin. Melasma, a common pigmentation disorder presented in some of the university students corresponds to $23(74.2 \%)$ females.

To avoid acne and melasma, the most frequent question was the non-use of sunscreen by $104(58.1 \%)$ of the students. Sunlight exposure $(n=87 ; 48.6 \%)$ indicated a medium level, and 101 (82.7\%) students did not use appropriate soap for the face.

A total of 110 university students (61.5\%) use makeup and $(n=36 ; 20.1 \%)$ said they did not remove the product from their face after use. The study also identified 152 (84.9\%) students with stress with a prevalence of female 106 (69.7\%).

Women $(n=76 ; 71 \%)$ declared dissatisfaction with acne on their face, while 29 (40.3\%) university men declared satisfaction with their facial appearance.

Of all the participants, a sample $(n=99 ; 55.3 \%)$ stated that they did not perform face treatment/intervention. Men (41.4\%) did not perform treatment/intervention on the face.

\section{Table II}

The data in Figure I reveal individuals up to 25 years old more affected by acne in all degrees, which corresponds to $88.3 \%$ of university students in this study. However, in all age groups grade II was prevalent. Students up to 25 years old (90.6\%) had comedones and papulopustular lesions. The percentage decreases for groups 26 to 30 years old $(9.1 \%)$ and over 30 years old only $(6 \%)$.

The Chi-square test related more scars in cases of acne grade II $(p=0,000)$. The Kruskal Wallis test revealed no statistical difference between the degree of acne and the participants' age range ( $\mathrm{Cl}: 0.09-0.23 ; \mathrm{p}=0.063)$.

\section{DISCUSSION}

The basis for the diagnosis of most dermatological disorders is physical examination and anamnesis. They aim to search for lesions related to the patient's main complaint ${ }^{19}$. Patients' habits, lifestyle, diet and hormonal age must be considered.

Evidence from different countries confirms acne prevalence in the world, especially during adolescence and early adulthood. Age-related acne results in psychosocial and physical sequelae ${ }^{20}$. According to the Global Burden of Disease 
Project, it estimates the prevalence of acne at $9.4 \%$ of the world's population, ranking it as the eighth most prevalent disease in the world ${ }^{21}$.

This information confirms the data from our study where $100 \%$ of the sample presented acne. The majority are young women, confirming the data from the literature that present this same epidemiological profile.

Moderate and severe acne affects approximately $20 \%$ of young people. Its severity is related to the maturity of puberty ${ }^{22}$, especially in women, due to the worsening of hormonal changes during the menstrual period ${ }^{23}$. The researches conclude acne affects young people ${ }^{22,23}$.

Food contributes to the onset of acne. According to this study, foods high in sugar and fat, such as frying $(78.8 \%)$, sweets $(74.3 \%)$ and soft drinks $(59.8 \%)$ are the most consumed by students.

Foods with a high glycemic index can contribute to the onset of acne ${ }^{24}$. This information emerges after comparing individuals with acne with the control group. a Meta-analysis developed in the USA indicates the relation between dairy intake and the development of acne, especially in young people and younger adults ${ }^{25}$.

A high-fat and high-glycemic diet results in hyperglycemia, which handles increasing testosterone production. So, these high testosterone levels stimulate the secretion of sebum by the sebaceous glands and generate acne ${ }^{26}$.

A study ${ }^{27}$ describes antiandrogen hormone dosages to avoid reproductive and metabolic repercussions, control inflammation, and reduce the aesthetic complications caused by acne. This would be another measure, besides food, to address the sequelae of acne on the face.

Another way to solve acne is by using make-up because they show fast results. The aesthetic treatment is often demanded by changes in the face, low self-esteem, and body dissatisfaction.

In this study, most university students claimed to use makeup to mask acne and melasma, a habit prevalent in women. The Brazilian Society of Dermatology states there is no problem in its use but warns the products to be oil-free. In some moments, makeup may be associated with some active ingredient to treat acne ${ }^{28}$.

According to the data, women use more makeup. A study ${ }^{29}$ in Ceará with $(n=$ 100) university women revealed they use makeup to improve beauty, correct skin 
imperfections, and raise self-esteem. Women feel beautiful and with high self-esteem, besides showing more concern with their appearance by using makeup.

Authors $^{30}$ associate the use of makeup with aggravation of acne. Greater use of this product, especially among young women, can be one of the factors that cause acne. Cleaning the face and removing makeup prevents the accumulation of dirt on the skin and reduces the chances of developing acne ${ }^{31}$.

Using sunscreen prevents the appearance of dyschromia and prevents the aggravation of acne. This also reduces hyperpigmented spots related to the inflammatory process of acne, prevents the comedogenic effect of sunlight exposure, and prevents the formation of melasma ${ }^{32}$.

A study at a university in Fortaleza-CE revealed that among 61 of the participants only 46 used sunscreen. This practice is good to reduce melasma ${ }^{33}$, a condition that affects women in reproductive age, particularly their faces ${ }^{34}$.

Only $15 \%$ of the total of 385 university students used sunscreen regularly ${ }^{35}$. Our research showed that out of 179 university students evaluated, only 104 (57.5\%) did not use sunscreen.

Stress is also pointed out as a factor in the development and worsening of acne. In this study, $84.9 \%$ of participants declared themselves to be stressed. Stress was the most commonly cited aggravating factor of acne, affecting about $50 \%(n=3305)$ of the study population. Research developed by Da Silva and Paes (2017) showed greater stress in individuals with acne (46.1\%) compared to the control group.

A study of 280 adults reported stress (58.2\%) and facial scars $(76.4 \%)$ as consequences of acne ${ }^{31}$. The severity and scars of acne compromise individuals on a psychosocial and professional way ${ }^{36}$.

Melasma and acne affect exposed areas of the face, impact on the perception of self-image, interpersonal relationships, and often in the perception of the quality of life ${ }^{37}$. Thus, in the present study, the level of dissatisfaction was more frequent in women, representing $71 \%$ of the total.

Cigarette smoking favors skin disorders, interferes with its quality and contributes to the emergence of acne. The agonistic effect of nicotine on cholinergic receptors of keratinocytes can lead to hyperkeratinization and hyperplasia of the infundibulum epithelium and elevation of oxidative stress, the formation of lipid peroxide (LPO) and its accumulation in comedones. So, it increases the levels of 
interleukin 1- $\alpha$ (IL-1 $\alpha)$, which induce abnormal follicular keratinization or inflammation, raising the chances of acne.

A survey ${ }^{38}$ showed that smokers $(n=28)$ had significantly higher levels of IL-1a and LPO in the comedones $(p<0.05)$ compared to non-smokers $(n=22)$. In our study only three individuals $(1.7 \%)$ smoked.

In recent decades the search for aesthetic treatments for young people has grown. The main objectives are to obtain a perfect appearance, influenced by the impositions of the media ${ }^{39}$. In this study, $44.7 \%$ of the interviewees had previously sought aesthetic treatment.

Idealization of the perfect body has been consolidating as a condition of social acceptance. This model is considered natural to achieve such standards, due the increasing number of individuals seeking gyms and aesthetics ${ }^{40}$.

The lack of a facial examination magnifying glass and insufficient demand from students to take part in this evaluation limited the study and implied the final quantitative of the research.

Women with papulopustular lesion grade II, acne scars, age up to 25 years, brown self-reported skin color, and family financial income from one to three wages were the greatest participants.

Stress and intake of fries and sweets were the habits most manifested by the university students researched. Acne is likely to be a condition of the scar mark.

The authors of this study emphasize the importance of health campaigns on the frequent use of sunscreen and the consumption of fruits and vegetables. The economic profile may affect habits so the health campaigns must consider the socio-cultural and financial diversity of individuals.

\section{Acknowledgements}

The authors of this study declare the initial participation of Prof. Dr. João Jaime Giffoni Leite (In Memoriam). 


\section{REFERENCES}

1- Giddon DB. Aplicações ortodônticas de estudos psicológicos e perceptuais da estética facial. In: Sadowsky PL, Peck S, King G. Laskin DM, editores. Atualidades em Ortodontia. São Paulo: Editorial Premier. 1997;79-88.

2- Lucena BB, Seixas CM, Ferreira FR. Ninguém é tão perfeito que não precise ser editado: fetiche e busca do corpo ideal. Psicol. USP. 2020;31. https://doi.org/10.1590/0103-6564e190113.

3- Tania Marur MD Yakup MD atum Selman Demirci MD Titulo: Facial anatomy. 2014;32(1):14-23.

4- Baudouin JY, Tiberghien G. Simetria, média e tamanho das características na atratividade facial das mulheres. Acta Psychol (Amst). 2004; 117:313-332.

5- Ngaage M, Agius M. The psychology of scars: A mini-review. Psychiatr. Danub. 2018;30:633-638.

6- $\quad$ Callou Filho CR. Avaliação e diagnóstico da situação em saúde. Callou Filho $\mathrm{CR}$, et al. Avaliação dos hidroxiácidos no tratamento de cicatrizes acneicas faciais: estudo de caso.1 $1^{\text {a }}$ edição. Campo Grande - MS: Editora Inovar;2020; v.1. cp.19. p.194-199. https://www.editorainovar.com.br/livros-academicos/

7- $\quad$ Micussi MTABC, Oliveira TCM, Meyer PF, Araújo FRO. Protocolo de avaliação facial: uma proposta fisioterápica. Fisioterapia Brasil, Suplemento especial.2008.

8- Silva AS, Sobrinho DDTM, Ramalho MP, do Nascimento MRL, Pessoa CV. Manifestações acneicas e a sequência do tratamento estético. Mostra Científica da Farmácia. 2017;3(1). 
9- Kede MPV; Sabatovich O. Dermatologia estética. In: Dermatologia estética. 2009;1024-1024.

10- Giraldo, J.C.S. Experiência personal em El manejo de La flaccidez corporal com radiofrequência. Anais do XVI Congresso Mundial de Medicina Estética. Argentina: Buenos Aires.2007; 11-14.

11- Guirro, E.; Guirro, R. Fisioterapia Dermato-funcional.3.ed. rev. e amp. São Paulo: Manole. 2004.

12- Bowe WP, et al. Body dysmorphic disorder symptoms among patients with acne vulgaris. Journal of the American Academy of Dermatology2007; 57(2): 222-230.

13- Fatma F, Baati I, Mseddi M, Sallemi R, Turki H, Masmoudi J. A report of 30 Tunisian women. European $\quad$ Psychiatry.2016;33: $\quad$ S327, 2016. DOI:10.1016/j.eurpsy.2016.01.1130

14- Pinto CDBS, Miranda ES, Moritz ÂFE, Osorio-de-Castro CGS. A provisão de medicamentos pelo "Saúde Não Tem Preço" em municípios prioritários para o Plano Brasil Sem Miséria em Mato Grosso do Sul. Physis: Revista de Saúde Coletiva.2018; 28:e280106, 2018. Doi:https://doi.org/10.1590/s0103-73312018280106

15. Fife D. Evaluation of acne scars: how to assess them and what to tell the patient. Dermatologic clinics. 2016; 34(2): 207-213.doi: 10.1016/j.det.2015.11.009.

16. Callou FCR, Leite JJG, Vieira EEA, Moura IFA. Forma, frequência e utilização de Fotoprotetores em universitários. Rev. Perspectiva \& Saúde. 2017;1(2): 23-27.

17. Petri, V. Dermatologia prática. 1a ed. Guanabara Koogan S.A. Rio de Janeiro, Cap 4 e 13, 2009.

18. Bagatina $E$, et al. Acne vulgar: prevalência e formas clínicas em adolescentes de São Paulo, Brasil. Rev. A. Bras. Dermatol.2014; 89(3). 
19. Soutor C, Hordinsky M. Dermatologia clínica. AMGH Editora, 2015.

20. Tan JKL, Bhate K. A global perspective on the epidemiology of acne. British Journal of Dermatology.2015; 172:3-12. DOI: https://doi.org/10.1111/bjd.13462

21. Hay RJ, Johns NE, Williams $\mathrm{HC}$ et al. A carga global de doenças de pele em 2010: uma análise da prevalência e impacto das condições da pele. J Invest Dermatol 2013;134:1527-34 .DOI: https://doi.org/10.1590/1980-5497201700050018.

22. Bhate, K.; Williams, H.C. Epidemiology of acne vulgaris. Br. J. Dermatol. 2013, 168, 474-485. https://doi.org/10.1111/bjd.12149

23. Poli F.; Dreno, B.; Verschoore, M. An epidemiological study of acne in female adults: results of a survey conducted in France. $J$ Eur Acad Dermatol Venereol.2001;15(6):541-545.

24. Da Silva MAM, Paes SDND. Estudo da relação entre a alimentação e a acne vulgar. Cadernos UniFOA.2018;12(35):123-133.

25. Juhl CR, Bergholdt HK, Miller IM, Jemec GB, Kanters JK, Ellervik C. Dairy intake and acne vulgaris: a systematic review and meta-analysis of 78,529 children, adolescents, and young adults. Nutrientes. 2018; 10(8):1049, 2018.

\section{https://doi.org/10.3390/nu10081049}

26. Scipioni G, Monteiro GC, Soldateli B. Acne e dieta: uma revisão. Nutrire Apr. 2015;40(1):104-109.

27. Cunha MGD, Moraes C, Cebrian G, Silva RFD, Reple SIF, Machado Filho CDA,et al. Dosages of androgenic hormones in adolescent patients with severe acne. Revista da Associação Médica Brasileira. 2020;66(1):36-41.DOI: https://doi.org/10.1590/1806-9282.66.1.36 
28. Sociedade Brasileira de Dermatologia [homepage na internet]. A maquiagem na pele acneica [acesso 20 mai 2020]. Disponível em: https://www.sbd.org.br/noticias/amaquiagem-na-pele-acneica/

29. Callou Filho CR. Avaliação e diagnóstico da situação em saúde. Farias LMA, Oliveira SP, Callou Filho CR, Maciel MMA, Rodrigues BKMM, Martins ABT. Avaliação do perfil do consumo de maquiagem em jovens universitárias da universidade de fortaleza unifor 1 a edição. Campo Grande - MS: Editora Inovar; 2020. v.1. cp.17.p.174182.https://www.editorainovar.com.br/livros-academicos/

30. Dreno B, Thiboutot D, Lay.ton AM, Berson D, Perez M, Kang S. Global Alliance to Improve Outcomes in Acne. Large-scale international study enhances understanding of an emerging acne population: adult females. Journal of the European Academy of Dermatology and Venereology. 2015;29(6):1096-1106.DOI: https://doi.org/10.1111/jdv.12757

31. Khunger N, Kumar CA clinico-epidemiological study of adult acne: is it different from adolescent acne?. Indian Journal of Dermatology, Venereology, and Leprology. 2012;78(3):335. DOI: 10.4103/0378-6323.95450.

32. Novadzki IM, et al. Acne na adolescência. Sociedade Brasileira de Pediatria.2018;1(9).

33. Callou Filho CR, Mesquita CAM, Teles JCMA, Vieira EEA, Mont'alverne DGB, Leite JJG. Fatores que interferem na satisfação corporal em universitários do sexo masculino. Rev. Conexão Ciência. Formiga/MG.2017;12(2):64-71.

34. Martin LK, Caperton C, Woolery-Lloyd H, Avashia N. Um estudo randomizado, duplo-cego, controlado por placebo, que avaliou a eficácia e a tolerabilidade dos leucotomos de Polypodium orais em pacientes com melasma. J Am Acad Dermatol. 2012;66(4). 
35. Urasaki MBM, Murad MM, Silva M, MaekawaTA ZG. Práticas de exposição e proteção solar de jovens universitários. Revista Brasileira de Enfermagem. 2016;69(1):126-133.http://dx.doi.org/10.1590/0034-7167.2016690117i.

36. Kokandi A. Evaluation of acne quality of life and clinical severity in acne female adults. Dermatol Res Pract. 2010.1-3. https://doi.org/10.1155/2010/410809

37. Fernandes PCA, Silmara M, Amante MH. Evaluation Instruments for Quality of Life Related to Melasma: An Integrative Review. Clinics. 2018; 73: e65. http://dx.doi.org/10.6061/clinics/2018/e65.

38. Yang YS, Lim HK, Hong KK, Shin MK, Lee JW, Lee SW, Kim NI. . Cigarette smoke-induced interleukin-1 alpha may be involved in the pathogenesis of adult $\begin{array}{llll}\text { acne. Annals of dermatology. 2014; 26(1):11-16. DOI: } & \end{array}$ https://doi.org/10.5021/ad.2014.26.1.11

39. Barros MD, Oliveira RPA. Tratamento estético e o conceito do belo. Caderno de Graduação-Ciências Biológicas e da Saúde-FACIPE. 2017;3(1):65.

40. Dos Santos ARM, Da Silva EAPC, De Moura PV, Dabbicco P, Da Silva PPC, De Freitas CMSM. A busca pela beleza corporal na feminilidade e masculinidade. Revista Brasileira de Ciência e Movimento. 2013;21(2):135-142. 